\title{
The Impact of Specific Banking, Industrial and Macroeconomic Factors on Bank Profitability: Evidence from the Albanian Banking System
}

\author{
Gazmend Nure \\ Department of Finance, Accounting and Tax, Free University of Berlin, Germany
}

Received: May 1, 2019 Accepted: May 24, 2019 Published: May 30, 2019

doi:10.5296/ber.v9i2.14724 URL: https://doi.org/10.5296/ber.v9i2.14724

\begin{abstract}
This research studies the factors that affect the profitability of the banking system in Albania during the period 2012-2017. The specific factors taken in the study are divided into two groups: the specific banking factors (internal), and the macroeconomic factors. The dependent variable used in the study, to measure Bank Profits, is Return on Equity (ROE). The empirical findings show that, when ROE is used as a dependent variable, all bank specific variables are negatively and significantly related to profitability. That being said, there is the exception of the liquidity factor (Liquid assets over short term liabilities) and bank size which has a positive.
\end{abstract}

Keywords: Commercial banks, Profitability, Determinants, Return on assets, Liquidity ratio

JEL Classification: G21; G24

\section{Introduction}

Albania is a country with an agriculture-industrial economy and the financial system is characterized by the dominant role of the banking sector, which plays the role of lanterns in the flow of funds into the economy. Whereas non-bank financial intermediaries, such as insurance companies and microcredit foundations, are still at an embryonic stage of development. Commercial banks are the main pillar of the financial system in Albania, providing opportunities for economic development and prosperity through various customer services.

According to Otuori (2013), commercial banks contribute to the economic growth of the country by providing funds for investors to borrow and deepen the country's finances. Unlike other emerging economies, the nature and resources of banking activity in Albania are generally based on domestic sources, such as deposits that the private sector and individuals 
place in the banking system.

The bank is a pillar of all industries and because every transaction involves money, the bank is the main pillar of funding. Haque and Tariq (2012) found in their study, strong banking system plays an important role in efficient allocation and utilization of loans. Profitability is the basic purpose of business creation and banks do not make exceptions.

The Albanian banking industry experienced various reforms, thus securing a strong banking industry that boosts economic activity. During the period $2000-2017^{2}$, was many mergers or acquisitions of banks. Effective and efficient operations of the financial sector are very critical in every economy because the financial sector, especially commercial banks, serve as fuel for running economic activities.

Various studies use different internal and external variables to explain banking profitability, showing the linkage of the absolute amount in revenue through the ability of a bank to increase its lender's credit rating and its profitability.

\subsection{The Bank Profitability in Albania}

The Albanian economy in the study period 2012-2017 has a slower but stable growth. At the beginning of the study period (2012), the Albanian economy is characterized by a relatively weak economic growth, due to high uncertainties, tight conditions financing and poor aggregate demand. Economic growth was not enough to utilize the country's productive capacities, generating weak demand-side inflationary pressures. Meanwhile, the performance of inflation is affected by weak aggregate demand, which has also determined the weakness of inflation over the last two years; the continuous reduction of imported inflation creates a strong volatility in total inflation. Figure. 1 shows that the inflation trend is fluctuating but in 2016 it reaches 2.2 percent, this increase is due to the weakening of external disinflationary pressures and rising pressures from internal demand (Central Bank of Albania 2016).

\subsection{The Albanian Banking Report 2017}

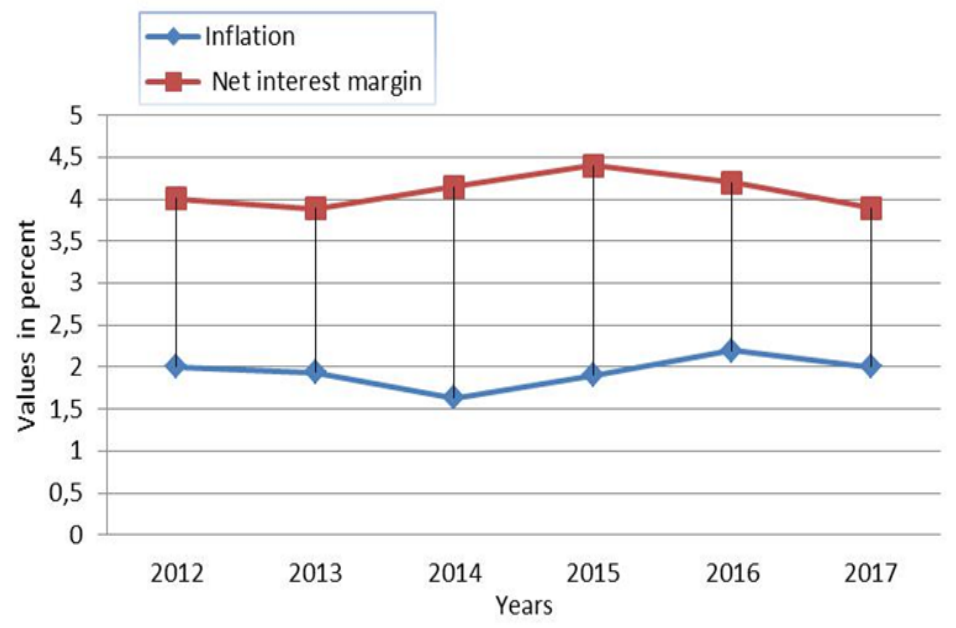

Figure 1. Performance of inflation and net interest margin indicators in the period 2012-2017 Source: by Author 


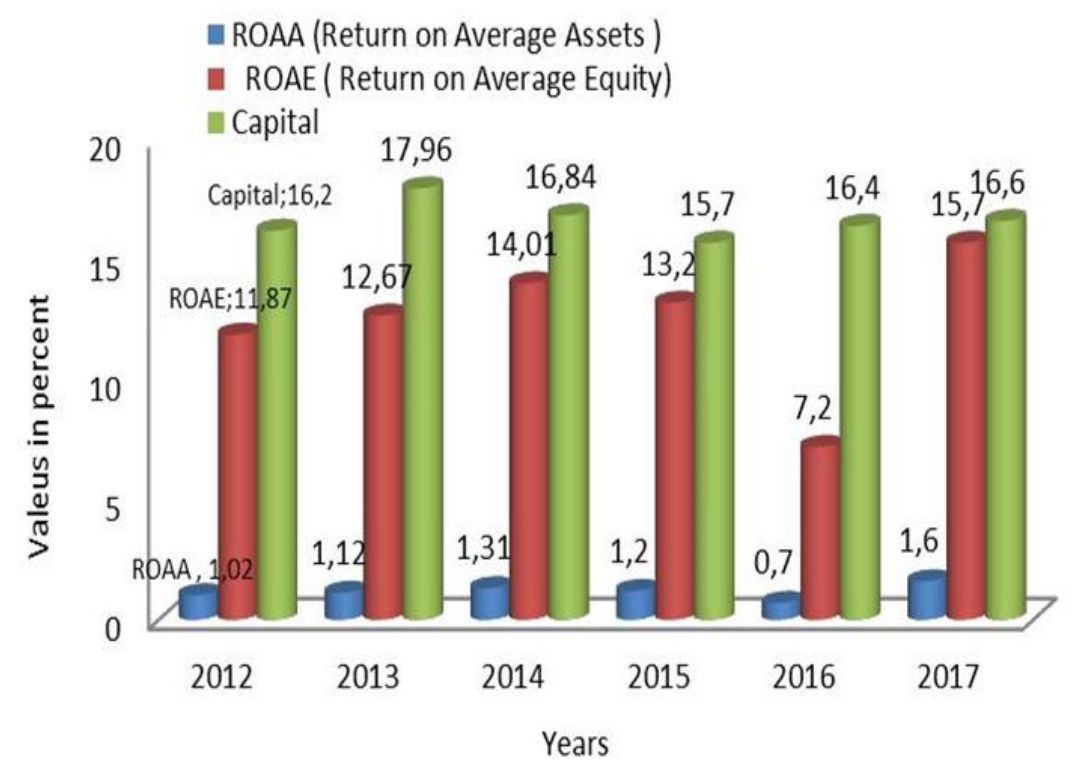

Figure 2. Performance of ROAA, ROAE and Capital indicators in the period 2012-2017

Source: by Author

The net interest margin represents the highest result in 2010 with a value of 4.4 percent as a result of lower interest expense compared to interest income, but this result is reversed at the end of 2017 , dropping by 0.5 percentage points. Referring to figure. 2 . The capitalization indicator remains stable for this study, in 2015 it goes down 15.7 percent as a result of the increase of risk assets against the regulatory capital.

Capitalization remains a characteristic of the Albanian banking system by supporting through the positive values of the net financial result. The banking sector is stable and has sufficient capital and liquidity to cope with the effect of fluctuations in the financial market. Average profitability indicators have an upward trend, only in 2016 they have lost a ROA decrease of 0.7 percent and ROE at 7.2 percent. The reason for the decrease of profitability of the banking system is the increase of the reserves of reserve funds (provisions) with 6 billion (lek) to credit risk.

\section{The Statement of the Problem}

Profitability is an important factor for good management of any business in today's competitive environment and has a significant impact on the performance of institutions. This study focuses on identifying key determinants of profitability, which provide an opportunity to know which variables affect the banks' profitability.

For this reason, researchers Mamatzakis, and Remoundos (2013) show in their study that internal and external factors play an important role in determining the banks profitability, not only for the owner but also for decision-makers who evaluate banks' performance in accordance with circumstances to increase their efficiency and profit. The study uses data from the annual reports of banks operating in the Republic of Albania during the time period 
2012-2017 in order to explore the relationship between determinate factors and their effects on profitability.

In this research, dependent variable is used to measure Banking Profitability, Return on Equity (ROE) is more appropriate according to Goddard et al. (2004), because it is expressed as the ratio of net profit after total taxation of share capital. Kalluru and Bhat (2008), suggest that Return on Equity (ROE) addresses the extent to which banks use equity to efficiently generate profits .Both of these dependent variables will be expressed in function of internal and external determinants. In the results of their works Sufian and Habibullah (2009) and Dietrich and Wanzenried (2011) shows that specific internal determinants are factors that are mainly influenced by bank management decisions and policy objectives.

In this study, five specific bank variables will be used as internal profitability determinants:

- Capital expressed as a ratio of Equity / Total Assets.

- Credit risk expressed as a ratio of Impaired Loans (NPLs) / Gross Loan s

- Liquidity that is expressed as Liquid assets over short term liabilities.

- Efficiency expressed as Cost to Income Ratio.

- $\quad$ Size expressed by Bank Size Logarithm of Total Assets (log).

Ramlall (2009) and Kosmidou (2008) suggest that external determinants are those related to macroeconomic conditions, and are also variables that reflect the economic and legal environment in which the financial institution operates .To analyze the impacts of external macroeconomic variables use GDP (Gross Domestic Product) and inflation.

\section{Literature Review}

So this research includes the banking environment study in Albania for the period 2012-2017 by analyzing external and internal factors affecting banks' profitability. The results of findings from Sufian and Chong (2008) and Dietrich and Wanzenried (2011) suggest that study of these variables is very important for executives, government and institutions, as they can evaluate through them the bank's effectiveness and their strategies to achieve the intended goals.

According to Hassan and Bashir (2003), the ratio of capital to total assets is the ratio of capital adequacy or solvency of a bank to cover the risk of unexpected losses. In his framework Athanasoglou et al. (2006) found that a high solvency leads to the reduction of risks taken by the bank. Thus, an increase in capital can increase expected earnings by reducing the expected costs of financial distress, including bankruptcy according to Berger (1995) and Dermiguc-Kunt A. and H. Huizinga (2000).

Liquidity is the ratio of liquid assets to short-term liabilities that indicates the impossibility of a bank to finance the increase in balance sheet assets or the impossibility to reduce the liability. Joel (2002) found on his research work that the liquidity risk is generated by the differences between assets and liabilities and the differences between their 
maturity .Therefore, the value of the current assets is not enough to meet the actual obligations and from this point of view, liquidity is a protective measure that helps take precautions in complicated situations by Bessis (2002).

High liquidity ratios usually bring lower rates of return shows Kosmidou (2008) on his findings. However, an "appropriate" ratio reduces the risk of failure that could lower funding costs and increase profitability suggest Alexiou and Sofoklis (2009). As few funds invest in long-term investments, the higher the profitability will be, according to Eichengreen and Gibson (2001). However, research from Bourke (1989) shows that there may be a positive relationship between liquidity and profitability.

Credit risk is the ratio of loan loss provisions to gross loans reflecting the probability of loss due to non-fulfillment of the liability to the bank. Increasing exposure to credit risk will lead to a decrease in profitability, therefore a high credit risk ratio negatively affects the bank's profitability according to Abreuand Mendes (2001) and Duca and McLaughlin (1990) and Hassan and Bashir (2003). Various studies have come to the same conclusion that increasing credit risk will increase the marginal cost of debt and equity, which in turn will expand the financing cost of the bank according to Basel I (2003).

The higher the exposure of the bank to the higher risk loans, the higher the accumulation of unpaid loans and lower is the profitability suggest by Miller and Noulas (1997). Sufian (2009) and Pervan and Guadagnino (2010) found on their findings a negative relationship between credit risk and profitability is expected, as loan loss provisions reduce bank profits.

In order to measure the efficiency of bank management, we use the ratio of total costs to total income and the high value of this report reflects less efficient management according to Kosmidou (2008). If we have a higher level of expenditure than income, then the profitability of the financial institution will be low. Therefore, cost reduction will improve management efficiency and increase bank profitability, implying here a negative relationship between the ratio of total costs to total income and benefit suggests by Bourke (1989) and Akbas (2012) and Dietrich and Wanzenried (2011).

Bank size is another component that different studies use to show there is a direct link between bank size and performance, but the effect is not very clear. The general asset logarithm variable is used to investigate the bank's size effect on profitability and is considered to be one of the most important determinants of bank profitability according to Kosmidou (2008). In general, Eichengreen and Gibson (2001) shows that increasing the bank size has positive effects on the benefit to some extent .However, Short (1979) shows that the size of the bank has a direct impact on the bank's profitability, affecting the growth in cost of capital for banks with large capital. This positive relationship between the bank size and profitability depends on whether there is a significant degree of economy that will lead to increase diversification and the latter will affect the reduction of credit risk and normally the rate of return will be ,suggests by Bikker and $\mathrm{Hu}$ ( 2002) and Goggard et al.( 2004) and Akhavein et al.(1997).

But the bank size may also have a negative impact on profitability for banks that become too 
large for bureaucratic and other reasons, therefore profit relationships may be non-linear according to Athanasoglou et al. (2008).

To analyze the impact of external macroeconomic factors affecting the bank's profitability, we use the GDP and inflation. GDP has a direct impact on the growth of customer deposits, granted loans, and interest margins. In periods when there is a GDP growth, banks give more loans and require higher margins, thus having a positive impact on the bank's profitability. When economic activity decreases, the demand for loans and deposits decreases and this affects negatively profit margins suggests by Sufian and Chong, (2008) and Kosmidou (2008).

Kosmidou (2008), inflation is another factor closely related to banks' profitability. There is a constructive and positive link between inflation and the profitability of the bank. High inflation is closely linked to high interest rates on loans and with high return on investment. It is always recommended that potential inflation expectations be made even though inflation is an unforeseeable factor. An unexpected change in the inflation rate can create problems in planning loans by creating faster growth of bank costs than on bank revenues and may also negatively affect the bank's profitability suggests by Hoggarth et al.(1998) and Smirlock, M. (1985). If bank management takes into account the possible inflation rate forecast, the bank will adjust the interest rates by increasing revenue faster than the expense, thus generating high profits. In the opposite case it may happen that the costs increase more in relation to the bank's income.

In order to achieve the objectives of this study, the following hypothesis was made and will be tested in this study:

- Ho: There is no relationship between independent variables and Profitability.

- H1o: Banks with higher liquidity ratio would be not able to achieve a better performance over the year of 2017.

\section{Research Methodology, Data and Results}

In the study, I have included not all the banks that carry out their activity in Albania. I made a selection considering some criteria such as: (size, availability of data, etc). The data are taken from the financial statements and the annual reports of 16 banks(Procredit, Raiffeisen, BKT, Intesa San Paolo Bank, FIbank, Tirana Bank, Credins Bank, Alpha bank, Veneto bank, Union bank, CIBank, UBA bank, Societe Gerneral Bank,NBG bank,BIA bank,Credit bank of Albania), while for the external and internal factors involved in the study, the data are obtained from the reports of the BOA (Central Bank of Albania) and from the database of the banks We will look at the variable ROE that affect the profitability of commercial banks. When analyzing the data relying on their heterogeneity and in order to achieve the best results, we used the multi linear regression analysis and Correlation with secondary data using a sample of data from banks and processing in this study will be done with Qi Macros Excel program. In Table 1 we have explained the dependent and independent variables along with their proxies. 
Table 1. Variables used in analysis. Source: Author calculations

\begin{tabular}{|l|l|}
\hline Panel A. Dependent Variable & Proxy factors \\
\hline ROE & The return on Equity ,Net profit / Equity \\
\hline Panel B. Independent Variables & \\
\hline Capital-Bank specific & Equity / Total Assets \\
\hline Credit risk-Bank specific factors & Impaired Loans(NPLs)/ Gross Loans \\
\hline Liquidity-Bank specific factors & Liquid assets over short term liabilities \\
\hline Efficiency-Bank specific factors & Cost to Income Ratio \\
\hline Size-Bank specific factors & \\
\hline Bank Size & Logarithm of Total Assets (log) of bank i at the time t \\
\hline GDP-Macroeconomic factors(External) & Gross Domestic Product (annual \%) \\
\hline Inflation-Macroeconomic factors(External) & Inflation (annual \%) \\
\hline
\end{tabular}

(1) Equation uses is :

Yit $=\alpha+\beta 1$ Capitalit $+\beta 2$ Credit riskit $+\beta 3$ Liquidityit $+\beta 4$ Efficiencyit $+\beta 5$ Sizeit $+\beta 6$ GDPit + $\beta 7$ Inflationit $+\varepsilon$

Where,

Yit $=$ profitability, $\mathrm{i}$ refers to an individual bank, $\mathrm{t}$ refers to year,

$\alpha=$ constant

$\mathrm{Bi}$ is the matrix of variable coefficients

$\varepsilon=$ Error term.

The main objective of this study is to find a relationship between variables defined in the paper as a determinant of bank profitability and profitability. Stationary of the expletory variables and the dependent variable of the model, was tested by using Augmented Dickey Fuller (ADF) test. Table 2 views the results which indicate the rejection of the unit root null hypothesis of the stationary of the research variables at the first difference.

Table 2. The results of unit root tests of independents variables on ROE

\begin{tabular}{|l|l|l|}
\hline Variables & ADF statistic & P-Value \\
\hline ROE & 14,6045 & 0,001 \\
\hline Capital & 3,7345 & 0,011 \\
\hline Credit Risk & 1,9078 & 0,001 \\
\hline Liquidity & 8,2036 & 0,020 \\
\hline Efficiency & 4,2304 & 0,000 \\
\hline Size & 9,5640 & 0,031 \\
\hline GDP & 3,9003 & 0,015 \\
\hline Inflation & 7,0293 & 0,005 \\
\hline
\end{tabular}

Source: Author computation from computer output 
Table 3. Descriptive Statistics

\begin{tabular}{|l|l|l|l|l|l|}
\hline Panel A. & N & Min & Max & Mean & Std.Dev \\
\hline ROE & 95 & $-0,21$ & 0,262 & 0,065 & 0,1 \\
\hline Panel B. & & & & & \\
\hline Capital & 95 & 0,078 & 0,187 & 0,118 & 0,032 \\
\hline Credit Risk & 95 & 0,023 & 0,305 & 0,142 & 0,093 \\
\hline Liquidity & 95 & 1,075 & 13,307 & 3,034 & 4,318 \\
\hline Efficiency & 95 & 0,326 & 2,558 & 0,786 & 0,384 \\
\hline Size & 95 & 13,006 & 17,131 & 14,393 & 1,28 \\
\hline GDP & 95 & 110 & 3,9 & 2,415 & 1,009 \\
\hline Inflation & 95 & 1,63 & 2,2 & 1,952 & 0,175 \\
\hline Shapiro-wilk test & P-value & W-stat & alpha & normal & \\
\hline ROE & 0,31 & 0,512 & 0,05 & yes & \\
\hline Capital & 0,12 & 0,662 & 0,05 & Yes & \\
\hline Credit Risk & 0,17 & 0,321 & 0,05 & Yes & \\
\hline Liquidity & 0,63 & 0,254 & 0,05 & Yes & \\
\hline Efficiency & 0,21 & 0,125 & 0,05 & Yes & \\
\hline Size & 0,13 & 0,324 & 0,05 & Yes & \\
\hline GDP & 0,10 & 0,256 & 0,05 & Yes & \\
\hline Inflation & 0,14 & 0,341 & 0,05 & yes & \\
\hline
\end{tabular}

Source: Author computation from computer output

Table 3 presents the basic descriptive statistics of variables values we used in the study for the study period 2012-2017. The surveyed banks have a ROE as an average value of 0.065; the maximum value is 0.262 , the minimum value is -0.210 with the standard deviation of 0.100 .

Another variable is capital for the same period has the following values: 0.187 maximum value, minimum value 0.078 , average value is 0.118 whereas standard deviation for this variable is 0.032 . The Credit Risk variable in the statistical analysis showed the following values: minimum value 0.023 , maximum value 0.305 , average value, standard deviation 0.142 and 0.093 .

The statistical values of the Liquidity variables are: Minimum value 1.075, maximum value is 13.307, the average value is 3.034 with standard deviation 4.318 . Efficiency has a minimum and maximum value of 0.326 to 2.558 , while the average value of 0.786 has a standard deviation of 0.384 . Size of the bank has the following values: 17.131 maximum value, minimum value 13.006 , the average value is 14.393 while the standard deviation for this variable is 1.280 . Also, Shapiro -Wilk test was used to verify the normality of the data, the hypotheses in this case are:

H0: The data are normally distributed

H1: The data are not normally distributed 


\section{Macrothink}

Business and Economic Research

ISSN 2162-4860

2019, Vol. 9, No. 2

The condition for the Shapiro Wilk test is: If, P- value <alpha at level 0.05, we reject the null hypothesis. The results of table 3 confirm that the data have normal distribution.

\subsection{Correlation Analysis}

The study conducted a correlation analysis between independent variables and commercial banks' profitability in Albania to find out the strength of the relationship between variables. Findings are presented in Table 4 below:

Table 4. Correlation analysis

\begin{tabular}{|c|c|c|c|c|c|c|c|c|}
\hline & ROE & Capital & $\begin{array}{l}\text { Credit } \\
\text { risk }\end{array}$ & Liquidity & Efficiency & Size & Inflation & GDP \\
\hline ROE & 1 & & & & & & & \\
\hline $\begin{array}{l}\text { Capital } \\
\text { t-statistic } \\
\text { p-value }\end{array}$ & $\begin{array}{l}-0,651 \\
-80,616 \\
1,44 \mathrm{E}-88 \\
\end{array}$ & 1 & & & & & & \\
\hline $\begin{array}{l}\text { Credit-risk } \\
\text { t-statistic } \\
\text { p-value }\end{array}$ & $\begin{array}{l}-0,533 \\
-59,214 \\
3,23 \mathrm{E}-76\end{array}$ & $-0,322$ & 1 & & & & & \\
\hline $\begin{array}{l}\text { Liquidity } \\
\text { t-statistic } \\
\text { p-value }\end{array}$ & $\begin{array}{l}0,626 \\
75,458 \\
6,54806 \mathrm{E}-86\end{array}$ & $-0,183$ & 0,696 & 1 & & & & \\
\hline $\begin{array}{l}\text { Efficiency } \\
\text { t-statistic } \\
\text { p-value }\end{array}$ & $\begin{array}{l}-0,752 \\
-94,34 \\
9,19309 \mathrm{E}-95\end{array}$ & $-0,113$ & $-0,277$ & 0,121 & 1 & & & \\
\hline $\begin{array}{l}\text { Size } \\
\text { t-statistic } \\
\text { p-value }\end{array}$ & $\begin{array}{l}0.571 \\
65,380 \\
3,62923 \mathrm{E}-80\end{array}$ & $-0,263$ & 0,585 & 0,047 & $-0,375$ & 1 & & \\
\hline $\begin{array}{l}\text { Inflation } \\
\text { t-statistic } \\
\text { p-value }\end{array}$ & $\begin{array}{l}-0,303 \\
-29,886 \\
8,60599 \mathrm{E}-50\end{array}$ & 0,011 & $-0,055$ & 0,005 & 0,157 & 0,054 & 1 & \\
\hline $\begin{array}{l}\text { GDP. } \\
\text { t-statistic } \\
\text { p-value }\end{array}$ & $\begin{array}{l}-0,367 \\
-37,085 \\
6,46 \mathrm{E}-58\end{array}$ & 0,050 & 0,027 & $-0,003$ & 0,030 & 0,076 & 0,320 & 1 \\
\hline
\end{tabular}

Source: Author calculations

From the above results, the findings show that there is a negative correlation between the capital, credit risk, efficiency and financial performance of commercial banks in Albania. The correlation results are as follows: $\mathrm{r}($ capital $)=-0.651, \mathrm{r}($ credit risk $)=-0,533, \mathrm{r}($ efficiency $)=-$ 0.752, a negative and significant correlation between these variables and financial performance of commercial banks in Albania . The correlation result is $r=0.626$ for liquidity and $r=0.571$ for bank size. In general, the findings conclude that there is a weak link between the inflation, the GDP and the profitability of commercial banks, the correlation results are as follows: $r$ (inflation) $=-0.303, r(G D P)=-0.367$. In cases such, we answer our 
research question concerning the existence of a linear relationship by using the t-test for testing the population correlation coefficient H0: $\rho=0$.First, we specify the null and alternative hypotheses:

- Null hypothesis H0: $\rho=0$

- Alternative hypothesis HA: $\rho \neq 0$ or HA: $\rho<0$ or HA: $\rho>0$

Rule: If the P-value is smaller than the significance level $\alpha$, and $\mathrm{t}>\mathrm{t}$ critic we reject the null hypothesis in favor of the alternative. We conclude "there is sufficient evidence at the $\alpha$ level to conclude that there is a linear relationship in the population between the predictor $\mathrm{x}$ and response y." The output from table 4, tells us that the $\mid \mathrm{t}$-statistics | is greater than $\mathrm{t}$-critic $(1,985)$. Therefore, the P-value of variables is less than 0.005. Since the P-value is smaller than 0.05 , we can reject the null hypothesis. There is sufficient statistical evidence at the $\alpha=$ 0.05 level to conclude that there is a significant linear relationship between dependent variable and independent variables. Table 5 shows that there is no multi-correlation between ROE and independent variables. As long as Tolerance values are 0,$99 ; 0,56 ; 0,76 ; 0,45 ; 0,78$; 0,61 and 0,89 greater than 0,2 and Variance inflation factors are $1 ; 1,7 ; 1,45 ; 1,10 ; 1,55 ; 1,62$ and 1,12 with smaller than 10 according to Saunders et al. (2009).

Table 5. Multi-collinearity Test

\begin{tabular}{|l|l|l|l|l|}
\hline Variable & Tol. & & $\mathbf{R}^{\wedge} \mathbf{2}$ & VIF \\
\hline Capital & & 0,99148012 & 0,00851988 & 1,0085931 \\
\hline Credit & & & & \\
\hline Risk & & 0,56479384 & 0,23546890 & 1,7085674 \\
\hline Liquidity & & 0,76090911 & 0,20195640 & 1,4503872 \\
\hline Efficiency & & 0,45002314 & 0,43023847 & 1,1023403 \\
\hline Size & & 0,78405632 & 0,34902812 & 1,5509867 \\
\hline GDP & & 0,61464568 & 0,38535432 & 1,62695359 \\
\hline Inflation & & 0,89125561 & 0,10874439 & 1,12201258 \\
\hline
\end{tabular}

Source: Author calculations.

\subsection{Regression Analysis and Hypothesis Testing}

The study conducted a regression analysis to test study hypotheses that predict the existence of a relationship between capital, credit risk, liability, efficiency, size, GDP, inflation and profit of commercial banks in Albania. The confidence level used is 95 percent testing the below hypothesis:

- H0- There is no statistically significant relationship between Capital and profitability.

- Ha- There is statistically significant relationship between Capital and profitability.

- H10- There is no statistically significant relationship between Credit risk and profitability.

- H1a- There is statistically significant relationship between Credit risk and profitability. 


\section{Macrothink}

Business and Economic Research

ISSN 2162-4860

2019, Vol. 9, No. 2

- H20- There is no statistically significant relationship between Liquidity and profitability.

- H2a- There is statistically significant relationship between Liquidity and profitability.

- H30- There is no statistically significant no relationship between Efficiency and profitability.

- H3a- There is statistically significant relationship between Efficiency and profitability.

- H40- There is no statistically significant relationship between Size and profitability.

- H4a- There is statistically significant relationship between Size and profitability.

- H5o- There is no statistically significant relationship between GDP level and profitability.

- H5a- There is statistically significant relationship between GDP level and profitability.

- H6o- There is no statistically significant relationship between Inflation and profitability.

- H6a- There is statistically significant relationship between Inflation and profitability.

The results are presented in the following tables: The model summary illustrates variation in variable dependent value which is explained by the regression model. The results are given in the table 6 below:

Table 6. Model summary

\begin{tabular}{|l|l|}
\hline Regression Statistics & \\
\hline Multiple R & 0,913 \\
\hline R Square & 0,833 \\
\hline Adjusted R Square & 0,791 \\
\hline Standard Error & 0,046 \\
\hline Observation & 96 \\
\hline
\end{tabular}

Source: Author calculations

From the results of tables 6 , it is shown that the multiple correlation coefficient is $r=0.913$. This shows that there is a correlation between independent and dependent variables. There is a correlation between the profitability of commercial banks in Albania and capital, credit risk, liquidity, efficiency, size, GDP, inflation. R2 is the determining coefficient that is variance in dependent variables that can be explained by independent variables in the regression model.

The results show a value of 0.833 meaning that independent variables explain 83 percent of commercial bank variability profitability. The standard error of regression is 0.046 , which is an estimate of the observable ROE variation, around the regression line. 
Table 7. Anova

\begin{tabular}{|l|l|l|l|l|l|}
\hline & Df & SS & MS & F & Significance F \\
\hline Regression & 6 & 0,289 & 0,041 & 19,942 & 0,000 \\
\hline Residual & 90 & 0,058 & 0,002 & & \\
\hline Total & 96 & 0,347 & & & \\
\hline
\end{tabular}

Source: Author calculations

By analyzing variance, we determine test Hypothesis if there is a relationship between ROE and independent variables taken in study. Results from the analysis of table. 7 Anova, we see that statistic F> F critical and P-value <0,005, we reject hypothesis null :Means are the same. Therefore, we reject the zero hypothesis, this means that there is a relationship between ROE and independent variable.

Table 8. Regression result

\begin{tabular}{|l|l|l|l|l|l|l|}
\hline Intercept & Coefficients & Std. Err & t-statistics & p-value & Lower 95\% & Upper 95\% \\
\hline Intercept & 0,20393 & 0,14743 & 1,38329 & 0,17751 & $-0,09806$ & 0,50592 \\
\hline Capital & $-1,71409$ & 0,44532 & $-3,84910$ & 0,00050 & $-2,61909$ & $-0,80909$ \\
\hline Credit risk & $-0,56802$ & 0,15481 & 3,66924 & 0,00083 & 0,25342 & 0,88262 \\
\hline Liquidity & 0,00291 & 0,00392 & 0,74208 & 0,00314 & $-0,00506$ & 0,01089 \\
\hline Efficiency & $-0,19504$ & 0,02936 & $-6,64397$ & 0,00000 & $-0,25470$ & $-0,13538$ \\
\hline Size ( log total asset) & 0,04127 & 0,01131 & 3,64943 & 0,00087 & 0,01829 & 0,06426 \\
\hline Inflation & $-0,05846$ & 0,09726 & $-0,60102$ & 0,04581 & $-0,25611$ & 0,13920 \\
\hline GDP & $-0,00658$ & 0,01689 & $-0,38947$ & 0,00936 & $-0,04090$ & 0,02774 \\
\hline
\end{tabular}

Source: Author calculations

The results in Table 8 show that variables are important for the regression model. Results show that the coefficient Capital is statistically significant at the $5 \%$ level with a probability of 0.00050 and implies a negative correlation between the variables. Keeping all other coefficients constant, an increase of 1 unit in the variable Capital will lead to an decrease in the variable ROE by $(-1,71409)$ units.

The regression analysis shows that the probabilities of Credit risk ,Efficiency, Inflation and GDP coefficients are $0.00083 ; 0,000 ; 0,04581 ; 0,00936$ and they are statistically significant at the $5 \%$ level and implies a negative correlation between the variables.

Results show that the coefficients of Liquidity and Size are statistically significant at the 5\% level with a probability of 0.00314 and 0,0087 and implies a positive correlation between variables. Keeping all other coefficients constant, an increase of 1 unit in the variable Liquidity or Size will lead to a decrease in the variable ROE by 0.0291 (Liquidity) units and 0,04127 (Size) units. The regression model obtained for this study is as follows; ROE = $0,20393-1,71409 *$ Capital $-0,56802 *$ Credit risk+0,00291*Efficiency $-0,19504 *$ Liquidity $+0,04127 *$ Size $-0,05846 *$ Inflation $-0,00658 *$ GDP 


\section{Testing Hypothesis II}

Banks with higher liquidity ratio would be able to achieve a better performance over the year of 2017?

To prove this hypothesis, banks are grouped into 2 groups according to their current report in 2017:

- Group (I) the banks with a ratio of liquidity higher than 1 (high liquidity bank); Group (II) the banks with a ratio of Liquidity less than 1 (low liquidity bank).

The relevant statistics for both groups are presented in Table 9, the first group consists of 10 banks $(62,5 \%)$ and the second group 6 banks $(37,5 \%)$. The idea is to compare ROE for both groups and see how it can be related to the hypothesis.

Table 9. High and low liquidity Banks' ROE statistics

\begin{tabular}{|l|l|l|l|}
\hline & Group(I) & Group(II) & \\
\hline Mean & High Liquidity & Low Liquidity & Total \\
\hline Standard Deviation & 0,34110807 & $-0,121915252$ & 0,1861572 \\
\hline Variance & 0,15284913 & $-0,061526396$ & 0,07701146 \\
\hline Number of Banks & 0,03279303 & $-0,001724442$ & 0,00593076 \\
\hline Std Err & 10 & 6 & 16 \\
\hline Minimum & 0,01465771 & $-0,01252068$ & 0,0157199 \\
\hline 1st Quartile & 0,1839278 & 0,028072674 & 0,02807267 \\
\hline Median & 0,19475826 & 0,096391645 & 0,13396332 \\
\hline 3rd Quartile & 0,23910477 & $-0,133837482$ & 0,18795493 \\
\hline Maximum & 0,24923837 & 0,150954527 & 0,2403809 \\
\hline Banka ROE> average ROE & 8 & 0,166664444 & 0,34248583 \\
\hline Banks ROE< average ROE & 2 & 2 & 10 \\
\hline
\end{tabular}

Source: Author calculations.

From average and average statistics we can observe that high liquidity banks usually had a better performance than the low liquidity group, both statistics were positive for group (I) and negative for group (II). The aviation was much higher for group(I), as we can see from the standard deviation. From the quartiles analyzes we can see observe that this higher variation majorly comes from the worse results from group (II), which were extremely lower then the minimum value observed for group (I).The difference between the first quartiles was of 0,098 , on the other side the difference for the third quartiles was only 0,099. Finally, it is interesting to note that from the first group only 2 bank (20\%) reported losses in 2017, while in the second group, 4 banks $(67 \%)$ had a negative income. So it clearly shows that there is a difference between the performance of banks with high liquidity and low liquidity banks during 2017, but to measure the importance of this change will execute a hypothesis testing procedure. The null hypothesis is that the average ROE for both groups is the same and the alternative hypothesis is that ROE for group (I) is higher than group (II), 
$\mathrm{H} 0: \mu \mathrm{a}=\mu \mathrm{b}$

$\mathrm{Ha}: \mu \mathrm{a}>\mu \mathrm{b}$

I used the t statistic to test the hypothesis and the test results tell us that the values of $\mathrm{P}$ (one tail--0, 0013) and (two tail-0,006) are less than 0.05, then we reject the null hypothesis, the Means are not the same. From result we confirm hypothesis 2, the banks with higher liquidity were able to achieve a better performance in 2017 then the banks with lower liquidity.

\section{Findings and Interpretation}

In Albania, the banking system has an important and direct role in the economic development of the country. Banks, as financial intermediaries, are the main promoter of maintaining the country's economic and financial stability. This research was difficult as far as database were concerned, as some banks did not reflect the data for the whole period studied, it is of particular importance as it will serve as a basis for further research.

Based on the study, other specific determinants could affect the bank's profitability, but at the same time the results will also be valid for the bank's management. In the study, we analyzed the factors affecting the profitability of banks in Albania for the period 2012-2017. As a determinant of bank profitability, both internal and external banking determinants were taken into account. Research findings show that there is a negative relationship between profitability and credit risk (which is expressed as the ratio of Impaired Loans (NPLs) / Gross Loans).

This factor has a direct and significant impact on banks' profitability, their relationship is linear. Increase ratio credit risk, decreases bank's profitability. This result is also due to the fact that during the study period (2012-2017), there was a significant decrease the profitability of banks because of the increase in value provision expense. Therefore, the management of banks should develop strategies to properly manage the credit risk through diversification of sources of income, in order to have stable levels and increasing their profitability. Also, efficiency factor coefficients have a negatively statistically significant level for ROE. This implies that the bank's management board should have attention to have the lowest value of credit risk ratio thus reducing costs and increase income in order to have the highest value on bank's profitability.

A negative relation was confirmed between capital and bank profitability which means that the higher the level of the bank capital, the lower the bank profitability will be. The results showed that the size of the bank has positive impact on the return on equity, because the size of the bank is important in terms of management efficiency, which means that the larger the bank wealth the higher bank profitability is. The liquidity factor (Liquid assets over short-term liabilities) has a beta coefficient relatively big and positive which makes it an relevant factor for its impact on the bank's profitability.

Concerning macroeconomic determinants, the findings indicate that inflation and GDP is negatively related and significant to the bank's profitability. In the Albanian banking system it seems that the operational costs of inflation have increased less than the effect of interest 
rates, but that this effect does not affect on bank's profitability. The study recommends that future researcher who has an interest in this study might test these variables in another sector for example microfinance banks and intend to extend the study incorporating other important factors, internal and external ones, which influence in profitability, such as: interest rates, exchange rates.

\section{Acknowledgement}

The research is financed by Einstein Foundation. No. 11746-C671. Thanks for department staff at Free University Berlin.

\section{References}

Abreu, M., \& Mendes, V. (2002). Commercial bank interest Margins and profitability: evidence from E.U. University of Porto Working Paper Series 122.

Akbas, H. E. (2012). Determinants of Bank Profitability: An Investigation on Turkish Banking Sector. Öneri Dergisi, 10, 103-110.

Akhavein, J. D., Berger, A. N., \& Humphrey, D. B. (1997). The effects of megamergers on efficiency and prices: Evidence from a bank profit function. Review of Industries Organization, 12, 95-139. https://doi.org/10.1023/A:1007760924829

Alexiou, C., \& Sofoklis, V. (2009). Determinants of bank profitability: Evidence from the Greek banking sector. Economic Annals, 54, 93-118. https://doi.org/10.2298/EKA0982093A

Athanasoglou, P. P., Brissimis, S. N., \& Delis, M. D. (2008). Bank-specific, industry-specific and macroeconomic determinants of bank profitability. Journal of International Financial Markets, Institutions and Money, 18, 121-136. https://doi.org/10.1016/j.intfin.2006.07.001

Athanasoglou, P. P., Delis, M. D., \& Staikouras, C. K. (2006). Determinants of Bank Profitability in the South Eastern European Region. Bank of Greece Working Papers 47.

Basel, I. (2003). International convergence of capital measurement and capital Standards. Basel Committee on Banking Supervision, June 2006. [Online] Available:

https://www.bis.org/publ/bcbs107.htm

Bashir A. M., \& Hassan M. K. (2003). Determinants of the Profitability in Islamic Banks: Some Evidence from the middle East. Islamic Economic Studies, 11.

Berger, A. (1995). The Relationship Between Capital and Earnings in Banking. Journal of Money, Credit and Banking, 27, 404-431. https://doi.org/10.2307/2077876

Bessis, J. (2002). Risk Management in Banking. (4rd ed.). New York: John Willey \& Sons.(Chapters 3, 4).

Bikker, J. A., \& Haixia H. (2002). Cyclical patterns in profits, Provisioning and lending of banks and procyclicality of the new Basel capital requirements. Banca Nazionale del Lavoro, 221, 143-175. [Online] Available: https://ideas.repec.org/a/psl/bnlqrr/200222.html

Bourke, P. (1989). Concentration and other determinants of bank Profitability in Europe, 
North America and Australia. Journal of Banking \& Finance, 13, 65-79. https://doi.org/10.1016/0378-4266(89)90020-4

Central Bank of Albania, Annual Report 2012-2017

Dermiguc-Kunt, A., \& Huizinga, H. (2000). Financial structure and Bank Profitability. Policy Research Working Paper Series 2430, The Word Bank.

Dietrich, A., \& Wanzenried, G. (2011). Determinants of Bank Profitability before and during the Crisis: Evidence from Switzerland. Journal of International Financial Markets, Institutions and Money, 21, 307-327. https://doi.org/10.1016/j.intfin.2010.11.002

Duca, J. V., \& McLaughlin M. M. (1990). Developments affecting the profitability of commercial banks. Board of Governors of the Federal Reserve System U.S. Bulletin issue Jul, pages 477-499.

Eichengreen , B., \& Gibson H. D. (2001). Greek banking at the dawn of the new Millennium. Centre for Economic Policy Research Discussion Paper 2791.

Goddard, J., Molyneux, P., \& Wilson, J. O. S. (2004). The profitability of European banks: a cross-sectional and dynamic panel analysis. The Manchester School, 72, 363-381. https://doi.org/10.1111/j.1467-9957.2004.00397.x

Haque, A., \& Tariq, A. (2012). Efficiency of Banks in Pakistan: A Non Parametric. Business \& Economic Research, 2, 23-45. https://doi.org/10.5296/ber.v2i1.1711

Hoggarth, M., \& Wood, G. E. (1998). Alternative routes to banking stability: A comparison of UK and German banking systems. Financial Stability Review, 5, 55-68.

Joel, B. (2002). Risk management in banking. Wese Sussex: John Wiley \& Sons.

Kalluru, S. R., \& Bhat S. (2008). An Empirical Analysis of Profitability Determinants in Indian Commercial Banks during Post Reform Period. University of ICFAI Journal of Industrial Economics, 5, 37-56.

Kosmidou, K. (2008). The Determinants of Banks' Profits in Greece during the Period of EU. Financial Integration Managerial Finance, 34, 146-159.

https://doi.org/10.1108/03074350810848036

Mamatzakis, E., \& Remoundos P. (2003). Determinants of Greek Commercial Banks Profitability, 1989-2000. University of Piraeus Spoudai, 53, 84-94. [Online] Available:

http://digilib.lib.unipi.gr/spoudai/handle/spoudai.

Miller, S., \& Athanasios N. (1997). Portfolio mix and large-bank profitability in the USA. Applied Economics, 29, 505-512. https://doi.org/10.1080/000368497326994

Otuori, H. O. (2013). Influence of exchange rate determinants on the performance of commercial banks in Kenya. European Journal of Management Sciences and Economics, 1, 86-98.

Pervan, M., Pervan, I., \& Guadagnino, A. (2010). Market Structure and Profitability of 


\section{Macrothink}

Business and Economic Research ISSN 2162-4860 2019, Vol. 9, No. 2

Croatian Commercial Banks. The Business Review, Cambridge, 16, 209-216.

Ramlall, I. (2009). Bank-Specific, Industry-Specific and Macroeconomic Determinants of Profitability in Taiwanese Banking System: Under Panel Data Estimation. International Research Journal of Finance and Economics, 34, 160-167. [Online] Available: https://www.researchgate.net/publication/255648655_Bank-Specific_Industry

Saunders, M. N., Lewis, P., \& Thornhill, A. (2009). Research methods for business students. (5rd ed.). Harlow: Pearson Education (Chapter 4).

Short, B. K. (1979). The relation between commercial bank profit rates and banking concentration in Canada, Western Europe, and Japan. Journal of Banking \& Finance, 3, 209-219. https://doi.org/10.1016/0378-4266(79)90016-5

Smirlock, M. (1985). Evidence on the (non) relationship between concentration and profitability in banking. Journal of Money, Credit and Banking, 17, 69-83. https://doi.org/10.2307/1992507

Spathis, C., Kosmidou, K., \& Doumpos, M. (2002). Assessing Profitability Factors in the Greek Banking System: A Multicriteria Methodology. International Transactions in Operational Research, 9, 517-530. https://doi.org/10.1111/1475-3995.00371

Sufian, F. (2009). Determinants of Bank Profitability in a Developing Economy: Empirical Evidence from the China Banking Sector. Journal of Asia Pacific Business, 10, 281-307. https://doi.org/10.1080/10599230903340205

Sufian, F., \& Chong, R. R. (2008). Determinants of Bank Profitability in a Developing Economy: Empirical Evidence from the Philippines. Asian Academy of Management Journal of Accounting \& Finance, 4, 91-112.

Sufian, F., \& Habibullah, M. S. (2009). Determinants of Bank Profitability in a Developing Economy: Empirical Evidence From Bangladesh. Journal of Business Economics \& Management, 10, 91-112. https://doi.org/10.3846/1611-1699.2009.10.207-217

\section{Copyright Disclaimer}

Copyright for this article is retained by the author(s), with first publication rights granted to the journal.

This is an open-access article distributed under the terms and conditions of the Creative Commons Attribution license (http://creativecommons.org/licenses/by/3.0/). 